\title{
The Microvascular Response of the Neonatal Mesentery to Hypertonic Feedings
}

\author{
JANET L. MELLER, STEPHEN A. WOLF, MARK K. FERGUSON, ROBERT L. C. REPLOGLE, \\ AND DENNIS W. SHERMETA
}

The University of Chicago, Pritzker School of Medicine, Chicago, Illinois 60637

\begin{abstract}
Using intravital microscopy we studied the responses of the jejunal and ileal mesenteric microcirculation to hypertonic meals in neonatal piglets. Test meals were infused through a cannulated segment of proximal jejunum. The intestinal segments were observed under conditions of controlled temperature and humidity, and the velocity of red blood cells through mesenteric arterioles was measured and blood flow calculated. Jejunal flow was not altered from baseline by saline or hypertonic manitol infusion, while significant increases in flow were observed during hypertonic glucose infusion $\left(3.8 \times 10^{-6}\right.$ versus 10.7 $\left.\times 10^{-6} \mathrm{ml} / \mathrm{s}, p<0.01\right)$. Jejunal glucose infusion did not cause shunting from the ileal microcirculatory bed. We conclude that the infusion of hypertonic glucose causes an increase in jejunal blood flow, but does not result in a change in ileal flow. The increase in flow is a local phenomenon related to glucose absorption in neonatal piglets. (Pediatr Res 20: 1136-1138, 1986)
\end{abstract}

\section{Abbreviation}

NEC, necrotizing enterocolitis

Intestinal blood flow in adult animals increases following ingestion of glucose and other hyperosmolar nonabsorbable substrates, however, the effects of these substances on neonatal intestinal blood flow have not been studied (1-6). The histopathology of NEC, a disease process characterized by diffuse areas of transmural intestinal necrosis, is suggestive of an ischemic etiology; moreover, some authors propose that feeding of hypertonic formulas to neonates contributes to the development of NEC (7-11). Because this and other diseases of digestion are major sources of morbidity in neonates, a thorough understanding of the responses of the neonatal intestinal circulation to feedings is of critical importance. This study examines the effect of hypertonic glucose feedings on the mesenteric microcirculation of neonatal piglets using intravital microscopy.

\section{MATERIALS}

Twenty-five neonatal piglets, less than 1 wk of age, weighing 1-3 kg, were anesthetized with $15.0 \mathrm{mg} / \mathrm{kg}$ ketamine and 13.5 $\mathrm{mg} / \mathrm{kg}$ pentobarbital intravenously. The external jugular vein was cannulated for infusion of fluids. The common carotid artery was cannulated and connected to a Simultrace Recorder (Electronics for Medicine-Honeywell VR-6) for continuous observation of arterial pressure. A tracheostomy was performed for

Received February 3. 1986: accepted June 10, 1986.

Correspondence and requests for reprints Janet L. Meller. M.D.. Wyler Children's Hospital. Division of Pediatric Surgery, 5841 S. Maryland Avenue, Box 163 , Chicago, IL 60637 control of the airway and management of secretions. Intravenous fluids consisting of $5 \%$ dextrose in lactated Ringer's solution were administered at a rate of $15 \mathrm{ml} / \mathrm{kg} / \mathrm{h}$. The electrocardiogram was monitored on the VR- 6 system. The jejunum and its mesentery were exteriorized through an infraumbilical transverse incision. The lumen of a $10-\mathrm{cm}$ section of proximal jejunum was cannulated at each end with $3 \mathrm{~cm}$ of polyvinyl tubing. The bowel mesentery remained in continuity and no vessels were divided.

The piglets were then transferred to a specially designed microscope stage. Body temperature was monitored and controlled with a heating pad and infrared lights. The bowel under observation was draped without tension over an observation chamber consisting of a hollow copper tube with a central lucite window through which a heated water bath was passed (Fig. 1). The remaining bowel was covered with saran film and aluminum foil to preserve moisture. A warmed $\left(38^{\circ} \mathrm{C}\right.$ ), deoxygenated (by debubbling with nitrogen gas) tris buffered solution with the following millimolar composition: $\mathrm{NaCl} 110, \mathrm{KCl} 5.0, \mathrm{NaHCO}_{3}$ $2.0, \mathrm{MgCl}_{2}$ 1.0, $\mathrm{NaHPO}_{4} 1.0, \mathrm{CaCl}_{2} 1.5$, and tris (hydroxymethyl aminomethane) 25 , suffused the bowel under observation at a rate of $5 \mathrm{ml} / \mathrm{h}$

The viewing system consisted of a Leitz Orthoplan microscope which was connected to a Cohu Model 4350 silicon diode low light video camera. The intestinal mesentery was transilluminated with a $100 \mathrm{~W}$ tungsten-halogen lamp and observed with an L32/0.4 lens. Two photodiodes were interposed between the objectives and the video camera, and their output fed into a velocity correlator [Instrumentation for Physiology and Medicine, San Diego, CA (IPM)] for measurement of centerline red blood cell velocity by the two-slit photometric method. The video signal was transmitted to a video shear monitor (IPM) for measurement of vessel diameters. Red blood cell velocity (V) and vessel diameter (D) were measured and blood flow (Q) in individual vessels was calculated as $Q=(V / 1.3) \pi\left(D_{2} / 4\right)$ for arterioles $10-20 \mu$ in diameter (12). The techniques used have previously been described (13-22). Terminal arterioles were chosen for observation in the edge of the mesentery close to the bowel wall and multiple observations over 5-min intervals were carried out per vessel during the 20-min infusion period.

There were five experimental groups of five piglets each. In group I, the surgical procedures were performed and no infusion was done. Group II, III, and IV animals received jejunal infusions of $0.9 \mathrm{~N}$ saline, mannitol (500 mosmol), and glucose $(500$ mosmol), respectively. Group V animals received glucose (500 mosmol) into the jejunal loop, while observations in this group were carried out on vessels in the terminal ileum of the animals. A total of $20 \mathrm{ml}$ of fluid per animal was infused through the proximal cannula for $20 \mathrm{~min}$ and allowed to drain from the distal cannula to avoid distension of the bowel. The animals were sacrificed at the conclusion of the study.

Each group of experiments was done in order and flows were not calculated until the entire study was completed so as not to prejudice the collection of data. Statistical evaluation was per- 
formed using the Student's $t$ test and all results were expressed as the mean \pm 1 SEM (23).

\section{RESULTS}

All piglets survived the experiment in stable condition maintaining a normal pulse and blood pressure. Insignificant variation was seen in single vessels in both velocity and diameter during the observation periods and recorded data represent the average of measured values for each vessel. In group I, where the surgical procedure was performed but no solution was infused, 11 vessels were observed. Red blood cell velocities ranged from 1.6 to 4.5 $\mathrm{mm} / \mathrm{s}$ with a mean of $2.7 \pm 0.325 \mathrm{~mm} / \mathrm{s}$. Diameter of vessels observed ranged from 10.9 to $19 \mu$ (mean $14.0 \pm 0.92 \mu$ ). Flows ranged from $1.2 \times 10^{-6}$ to $9.8 \times 10^{-6} \mathrm{ml} / \mathrm{s}$ (mean $3.8 \times 10^{-6} \pm$ $0.97 \times 10^{-6} \mathrm{ml} / \mathrm{s}$ ) (see Table 1).

In group II, normal saline was infused into the jejunal loop for $20 \mathrm{~min}$, and eight vessels were observed. Red blood cell velocities ranged from 2.0 to $4.5 \mathrm{~mm} / \mathrm{s}$ (mean $2.56 \pm 0.29 \mathrm{~mm} /$ s). Diameters ranged from 13 to $19.2 \mu$ (mean $15.2 \pm 0.94 \mu$ ). Flows were calculated and ranged from $2.0 \times 10^{-6}$ to $5.5 \times 10^{-6}$ $\mathrm{ml} / \mathrm{s}$ (mean $3.6 \times 10^{-6} \pm 0.45 \times 10^{-6} \mathrm{ml} / \mathrm{s}$ ). The differences between groups I and II were not statistically significant.

Mannitol (500 mosmol) was infused over $20 \mathrm{~min}$ into the

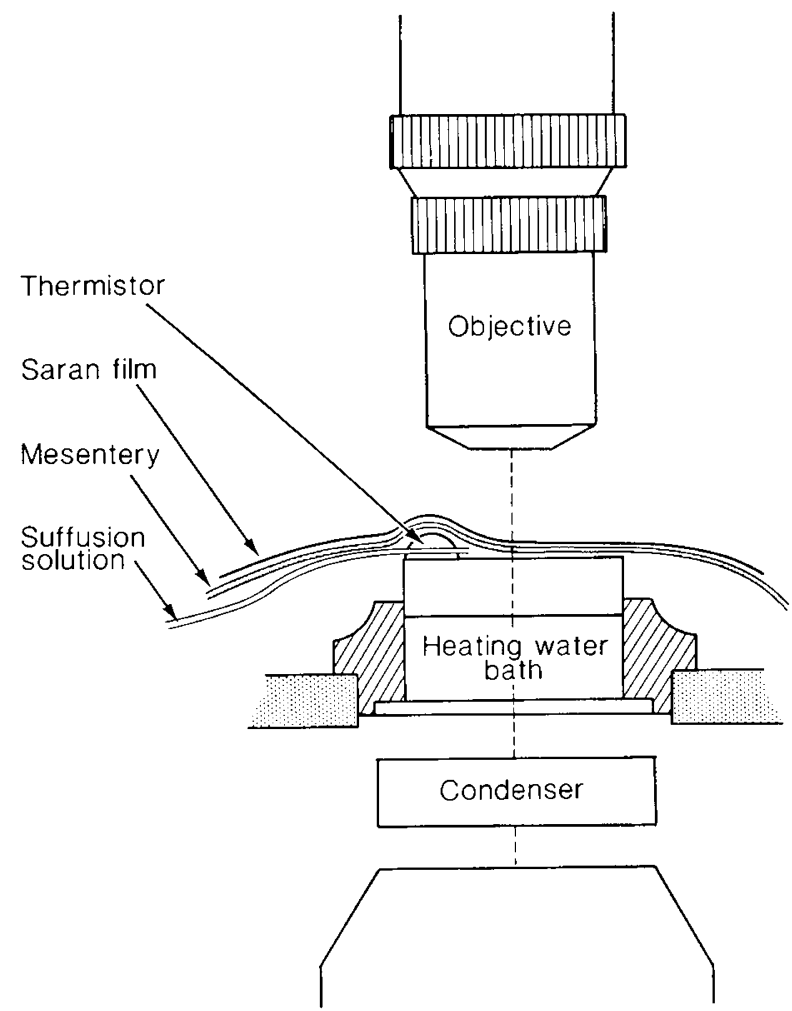

Fig. 1. The observation chamber with mesentery in place. jejunal loops of animals in group III. Fourteen vessels were observed. Velocities of the red blood cells ranged from 2.2 to 4.5 $\mathrm{mm} / \mathrm{s}$ (mean $2.99 \pm 0.19 \mathrm{~mm} / \mathrm{s}$ ) and diameters ranged from 10.6 to $19.6 \mu$ (mean $16.4 \pm 0.76 \mu$ ). Calculated flows ranged from $2.1 \times 10^{-6}$ to $10.4 \times 10^{-6} \mathrm{ml} / \mathrm{s}$ (mean $5.1 \times 10^{-6} \pm 0.7 \times$ $10^{-6} \mathrm{ml} / \mathrm{s}$ ). The differences between groups I and III were not statistically significant.

Animals in group IV had a 500 mosmol glucose solution infused into their jejunal loops. Thirteen vessels were observed in this group. The red blood cell velocities ranged from $4.5-16.0$ $\mathrm{mm} / \mathrm{s}$ (mean $8.85 \pm 0.94 \mathrm{~mm} / \mathrm{s}$ ) and vessel diameters ranged from $10-19 \mu$ (mean $13.55 \pm 0.9 \mu$ ). Calculated flows ranged from 2.7-27.9 $\times 10^{-6} \mathrm{ml} / \mathrm{s}$ (mean $10.7 \times 10^{-6} \pm 1.96 \times 10^{-6}$ $\mathrm{ml} / \mathrm{s}$ ). The difference between flows in group I and group IV was statistically significant at $p<0.01$.

In group V animals, a 500 mosmol solution of glucose was infused into the jejunal loop, however, observations were carried out on arterioles located in the mesentery of the terminal ileum. Baseline measurements were carried out prior to infusion of the jejunal loop. Red blood cell velocities in the nine vessels observed prior to infusion ranged from $2.0-5.0 \mathrm{~mm} / \mathrm{s}$ (mean $3.56 \pm 0.39$ $\mathrm{mm} / \mathrm{s}$ ) and diameters ranged from $10-19 \mu$ (mean $13.9 \pm 0.93$ $\mu$ ). Flows ranged from $1.5 \times 10^{-6}$ to $10.9 \times 10^{-6} \mathrm{ml} / \mathrm{s}$ (mean 4.6 $\left.\times 10^{-6} \pm 1.0 \times 10^{-6} \mathrm{ml} / \mathrm{s}\right)$. Fifteen vessels were observed after infusion of the jejunal loop was begun and red blood cell velocities ranged from 1.7 to $6.0 \mathrm{~mm} / \mathrm{s}$ (mean $3.98 \pm 0.459 \mathrm{~mm} / \mathrm{s}$ ) and arteriolar diameters ranged from 10.3 to $20 \mu$ (mean $16 \pm$ $0.66 \mu$ ). Flows were found to range from $1.2 \times 10^{-6}$ to $16.1 \times$ $10^{-6} \mathrm{ml} / \mathrm{s}$ (mean $6.49 \times 10^{-6} \pm 1.1 \times 10^{-6} \mathrm{ml} / \mathrm{s}$ ). There was no statistically significant difference between flows in the baseline and infused states or between flows in the control group I and the infused group V (see Table 2).

\section{DISCUSSION}

The study of the intestinal and mesenteric microcirculatory bed has been accomplished with a number of techniques including intravital microscopy, Doppler flow probes, radiolabeled microspheres, and radioactive zenon gas. Intravital microscopy was chosen for this study because it allows for in vivo studies of the microcirculation without the administration of foreign sub-

Table 2. Ileal mesenteric microvascular blood flow during jejunal intraluminal glucose infusion

\begin{tabular}{|c|c|c|c|c|}
\hline & \multicolumn{2}{|c|}{$\begin{array}{l}\text { Red blood cell } \\
\text { velocity }\end{array}$} & \multicolumn{2}{|c|}{ Blood flow } \\
\hline & Baseline & $\begin{array}{c}\text { Glucose } \\
00 \text { mosmol) }\end{array}$ & Baseline & $\begin{array}{c}\text { Glucose } \\
(500 \text { mosmol) }\end{array}$ \\
\hline Jejunal loop (control) & $\begin{array}{l}2.7 \\
(\mathrm{~mm} / \mathrm{s})\end{array}$ & & $\begin{array}{l}3.8 \times 10^{-6} \\
(\mathrm{ml} / \mathrm{s})\end{array}$ & \\
\hline Ileal loop & $\begin{array}{l}3.56 \\
(\mathrm{~mm} / \mathrm{s})\end{array}$ & $\begin{array}{l}3.98 \\
(\mathrm{~mm} / \mathrm{s})\end{array}$ & $\begin{array}{l}4.6 \times 10^{-6} \\
(\mathrm{ml} / \mathrm{s})\end{array}$ & $\begin{array}{l}6.5 \times 10^{-6} \\
(\mathrm{ml} / \mathrm{s})\end{array}$ \\
\hline
\end{tabular}

Table 1. Jejunal mesenteric microvascular blood flow during intraluminal infusions

\begin{tabular}{|c|c|c|c|c|}
\hline & \multicolumn{4}{|c|}{ Group } \\
\hline & $\begin{array}{c}\mathrm{I} \\
(\text { Control })\end{array}$ & $\begin{array}{c}\text { II } \\
\text { (Normal saline) }\end{array}$ & $\begin{array}{c}\text { III } \\
\text { (Mannitol) } \\
(500 \text { mosmol })\end{array}$ & $\begin{array}{c}\text { IV } \\
\text { (Glucose) } \\
(500 \text { mosmol })\end{array}$ \\
\hline $\begin{array}{l}\text { Jejunal red blood cell velocity } \\
\qquad(\mathrm{mm} / \mathrm{s})\end{array}$ & 2.7 & 2.56 & 2.99 & $8.85^{*}$ \\
\hline Jejunal blood flow $(\mathrm{ml} / \mathrm{s})$ & $3.8 \times 10^{-6}$ & $3.6 \times 10^{-6}$ & $5.1 \times 10^{-6}$ & $10.7 \times 10^{-6 *}$ \\
\hline
\end{tabular}

$* p<0.01$ (group I different from group IV). 
stances (e.g. microspheres). In addition, single vessels can be observed, repeated observations can be made, and changes in flow documented as they occur. The mesenteries of most mammalian species have similar patterns and provide an excellent subject for intravital microscopy due to ease of transillumination $(25,26)$. Disadvantages of the technique include a size constraint on the vessels able to be observed effectively in that very small or large vessels may give artifactual readings; moreover, shunting may occur at the capillary level with closure of capillaries and small arteriovenous communications. This does not appear to influence inflow into the microvascular bed (1); however, larger arterioles were chosen to obviate this problem and because they represent the source of microvascular flow regulation. Another disadvantage is the need for the tight control of experimental conditions. Changes in humidity or stretch on the vascular bed may introduce artifact, thus, observation times must be limited. Within these constraints, however, intravital microscopy allows for observations of changing conditions within the subject similar to those which might occur in vivo rather than in postmortem analysis.

Adults have been found to respond to ingestion of glucose meals with a generalized increase in intestinal blood flow $(1,2$, 4-7). During this time, coronary and renal vascular flows remain at normal levels (23). In addition, hypertonic nonabsorbable substances are associated with similar increases in blood flow although these increases may occur for different reasons and by different mechanisms $(3,6)$. This appears to be a regional phenomenon, being confined to the portion of gut which is involved in the absorptive process. The increase is seen most prominently in the mucosal layer of the gut wall, although it is seen to some extent throughout the segment's vascular bed $(2-4,6)$.

NEC is a disease of neonates in which segments of intestine, particularly the terminal ileum and ascending colon, become necrotic $(7,9)$. The hypertonicity of feedings may contribute to the development of NEC as a consequence of the inability of the immature neonatal intestinal tract to process feedings appropriately $(10,11)$, although some contend that the neonate will shunt blood to areas where it is needed with resultant ischemia in other intestinal segments (24). Further elucidation of the normal responses of the neonatal intestinal tract is important in the understanding of the pathophysiology of NEC, a major source of morbidity and mortality in the neonate.

We were interested in determining whether neonates respond to a hypertonic load as adults do with an increase in intestinal mesenteric blood flow. As this study demonstrates, neonates do respond to hypertonic glucose meals with an increase in intestinal mesenteric blood flow which appears to be confined to the portion of the gut involved in the absorptive process, however, in contrast to adults, the increase is related specifically to the presence of glucose in the gut lumen. The intraluminal presence of a nonabsorbable hyperosmolar solution in the neonatal gut does not lead to a comparable increase in intestinal mesenteric blood flow. In addition, this study demonstrates that the presence of glucose in the jejunal segments does not result in obvious shunting from the terminal ileum.

In conclusion, normothermic, normovolemic neonatal piglets respond to the presence of a hypertonic glucose load by increasing local intestinal blood flow in the mesenteric microcirculation. These increases are accomplished without shunting from more distal areas in the intestinal tract. Thus the requirements for increased intestinal blood flow in the proximal intestine secondary to the presence of a hypertonic glucose load do not result in distal intestinal ischemia. In contrast, the intestinal tract of the neonatal piglet does not react, as does that of adults, to the specific presence of a nonabsorbable hyperosmolar load with a comparable hyperemic response. Future avenues for study would include the introduction of other substances into the loop preparation to study their effects on blood flow as well as repetition of the experiments in hemodynamically compromised animals.

\section{REFERENCES}

1. Bohlen $\mathrm{HG} 1980$ Intestinal tissue $\mathrm{PO}_{2}$ and microvascular response during glucose exposure. Am J Physiol 238:H164-H171

2. Jacobson ED, Gallavan RH Jr, Fondacaro JD 1982 A model of the mesenteric circulation. Am J Physiol 242:G54 1-G546

3. Kvietys PR, Pittman RP, Chou CC 1976 Contribution of luminal concentration of nutrients and osmolality to postprandial intestinal hyperemia in dogs. Proc Soc Exp Biol Med 152:659-663

4. Pawlik WW, Fondacaro JD, Jacobson ED 1980 Metabolic hyperemia in canine gut. Am J Physiol 239:G12-G17

5. Shepherd AP 1979 Intestinal capillary blood flow during metabolic hyperemia. Am J Physiol 237:E548-E554

6. Sit SP, Nyhof R, Gallavan R, Chou CC 1980 Mechanisms of glucose-induced hyperemia in the jejunum. Proc Soc Exp Biol Med 163:273-277

7. Thomas FFM 1982 Pathogenesis of neonatal necrotizing enterocolitis. J Soc Med 75:838-840

8. Towloukian RJ, Posch JN, Spencer R 1972 The pathogenesis of ischemic gastroenterocolitis of the neonate: selective gut mucosa ischemia in asphixiated neonatal piglets. J Pediatr Surg 7:194-205

9. Wijesinha SS 1982 Neonatal necrotising enterocolitis: new thoughts for the "eighties. Ann R. Coll Surg Engl 64:406-409

10. Book LS, Herbst JJ, Atherton SO, Jung AL 1975 Necrotizing enterocolitis in low-birth-weight infants fed an elemental formula. J Pediatr 84:602-605

11. deLemos RA, Rogers JH Jr, McLaughlin GW 1974 Experimental production of necrotizing enterocolitis in newborn goats. Pediatr Res 8:380(abstr)

12. Lipowsky HH, Zweifach BW 1978 Application of the "two slit" photometric technique to the measurement of microvascular volumetric flow rates. Microvasc Res 15:93-101

13. Gaehtgens P, Meiselman HJ, Wayland H 1970 Erythrocyte flow velocities in mesenteric microvessels of the cat. Microvas Res 2:151-162

14. Gore RW 1973 Mesenteric preparations for quantitative microcirculatory studies. Microvasc Res 5:368-375

15. Hershey SG, Zweifach BW, Rovenstine EA 1953 Effects of depth of anesthesia on behavior of peripheral vascular bed. Anesthesiology 14:245-254

16. Intaglietta M, Tompkins WR 1973 Microvascular measurements by video image shearing and splitting. Microvasc Res 5:309-312

17. Intaglietta $M$, Tompkins WR, Richardson DR 1970 Velocity measurements in the microvasculature of the cat omentum by on-line method. Microvasc Res 2:462-473

18. Wayland H 1973 Photosensor methods of flow measurement in the microcicrulation. Microvasc Res 5:336-350

19. Zweifach BW 1957 General principles governing the behavior of the microcirculation. Am J Med 23:684-696

20. Zweifach BW 1973 The microcirculation in the intestinal mesentery. Microvasc Res 5:363-367

21. Smaje LH, Fraser PA, Clough G 1980 The distensibility of single capillaries and venules in the cat mesentery. Microvasc Res 20:358-370

22. Vatner SF, Patrick TA, Higgins CB, Franklin D 1974 Regional circulatory adjustments to eating and digestion in conscious unrestrained primates. $\mathbf{J}$ Appl Physiol 36:524-529

23. Steel RG, Torrie JH 1980 Principles and Procedures of Statistics: A Biometrical Approach. McGraw, New York, pp 540-544

24. Lloyd JR 1969 The etiology of gastrointestinal perforations in the newborn. J Pediatr Surg 4:77-84

25. Zweifach BW 1954 Direct observations of the mesenteric circulation in experimental animals. Anat Rec 120:271-291

26. Chambers R, Zweifach BW 1944 Topography and function of the mesenteric capillary circulation. Am J Anat 75:173-205 